УДК 347.24

DOI https://doi.org/10.32837/pyuv.v0i2(27).184

\author{
Є.I. Палиулич \\ здобувач \\ Національної академії Служби безпеки України
}

\title{
ПРОБЛЕМНІ ПИТАННЯ ПРИВАТИЗАЦІЇ НЕМАТЕРІАЛЬНИХ АКТИВІВ ТА ЇХ ВПЛИВ НА ДЕРЖАВНІ ІНТЕРЕСИ
}

Мета статті - розкриття негативних аспектів роздержавлення та характеристика негативних факторів і реальних загроз стабільному економічному розвитку України в приватизаційній сфері, висвітлення результатів діяльності Фонду державного майна України з викриттям фактів порушень у процесі реформування державної власності. Завдання статті - розгляд особливостей приватизації нематеріальних активів, їх законодавчого врегулювання та достатність контролю у процесі визначення критеріїв належності об'єктів до об'єктів стратегічного, загальнодержавного значення і критичної інфраструктури, що зумовлює недосконалість процедур із відображення фінансової звітності, аудиту, інвентаризації та оцінки.

Стан приватизаційних реформ в Україні характеризується періодичним неврахуванням й ігноруванням важливих аспектів, які прямо впливають на державні інтереси та регулюють суспільні потреби. За відсутності належного регулювання приватизації державних підприємств виникає казус у забезпеченні інтересів держави, інститути якої не можуть повною мірою реагувати на процеси, що потребують контролю відповідно до принципів міжнародного права (зокрема «Конвенції про захист прав людини і основоположних свобод» 1950 р., що ратифікована 17.07.1997 p.).

Реформування власності через приватизаційні процеси пов'язане із забезпеченням чіткої взаємодії приватних і публічних інтересів, а також дотриманням всіма суб'єктами чинного законодавства. Державне управління майновими перетвореннями під час економічної нестабільності, зміна форм власності й утворенням нових власників приватизаційним шляхом мають перебувати під пильним наглядом контролюючих структур. На наш погляд, чим глибші кризові явища, тим активніше мають застосовуватися заходи державного моніторингу, впливу і контролю для недопущення нехтуванню національних пріоритетів й загроз розбалансування державного сектору економіки. Вказане необхідне, у тому числі, для недопущення обмежень права держави володіти належним їй майном, яке необхідне державним інститутам із метою дотримання загальних інтересів суспільства загалом і кожного громадянина України зокрема.
Особистий інтерес приватних структур має стримуватися державними органами, до яких у приватизаційній сфері зараховано Фонд державного майна України як центральний орган виконавчої влади із спеціальним статусом, що реалізує державну політику у сфері приватизації, оренди, використання та відчуження державного майна, управління об'єктами державної власності, у т.ч. корпоративними правами держави. Державний регулятор зобов'язаний враховувати всі елементи і потреби держави в їі існуванні й розвитку, особливо під час приватизації суб'єктів господарювання певних галузей та сфер, які обслуговують загальнодержавні інтереси та впливають на її економічну безпеку. У процесі приватизації мають дотримуватися критерії «економічної доцільності» передачі об'єктів приватним власникам, а також «державного інтересу» відчуження, засади якого закріплені Конституцією України (ст. ст. 1, 3, 7, $8,12)$, законами України «Про приватизацію державного і комунального майна» (ст.ст. $2,4,10)$ i «Про Фонд державного майна України» (ст. ст. 4, $5)$.

Враховуючи зазначене, доцільно розглянути важливий елемент, який недостатньо враховується під час приватизації державних підприємств й подекуди використовується для незаконного привласнення зацікавленими особами національних надбань - відображення серед державного майна нематеріальних активів, що включаються до приватизаційної маси основних засобів підприємства. Зазначене впливає на вартість єдиного майнового комплексу, а також на загальне обчислення реальної (із зазначенням частки у статутному фонді) вартості акції, що вираховується під час приватизації. Таким чином, всі активи, в тому числі й нематеріальні, характеризують фактичну вартість державної частки, яка пропонується до відчуження, а також впливають на критерії оцінки самого об'єкта приватизації - чи підпадає він під відчуження та чи належить до підприємств, які не підлягають роздержавленню.

Належне врахування нематеріального активу у процесі приватизації державних підприємств гарантуватиме дотримання прав держави, зокрема й корпоративне, що реалізуватиметься через належне відображення фінансової звітності, аудит, інвентаризацію та оцінку. Отже, під 
час прийняття рішення про приватизацію й визначення способу роздержавлення ФДМ України має враховувати всі поступальні кроки й можливі ризики втрати такого специфічного державного активу, як нематеріальний - немонетарний актив, що не має матеріальної форми, може бути ідентифікований та утримується 3 метою використання у виробництві, торгівлі, адміністративних цілях чи наданні в оренду (визначається п. 14.1.120 ст. 14 Податкового кодексу України). Особливо це стосується прав на користування природними ресурсами і прав користування окремо визначеним майном, яке має відображатися на субрахунку № 424 «Безоплатно одержані необоротні активи», де обліковується вартість необоротних активів, що безоплатно одержані підприємством від його засновників, переданих в оренду або ж спрямованих як внесок до статутного капіталу. Залежно від цілі переданого необоротного активу його по-різному відображають. Так, при безоплатному одержанні необоротних активів його дебетують рахунки № 10 «Основні засоби», № 11 «Інші необоротні матеріальні активи», № 12 «Нематеріальні активи» i кредитують субрахунок № 424 «Безоплатно одержані необоротні активи» . $\mathrm{y}$ разі внеску до статутного фонду на субрахунку № 425 «Інший додатковий капітал» обліковуються інші види додаткового капіталу, які не можуть бути включені до наведених вище субрахунків, оскільки він є суттєвою частиною власного капіталу, від якого залежить загальна ціна майна підприємства.

Як свідчить сьогодення, нормативно-правове забезпечення вказаного питання, яке прямо впливає на приватизаційну сферу, загалом недостатне і потребує покращення законодавчого регулювання. Причиною негативних наслідків приватизації є відсутність норм, які б чітко регулювали процес обліку та відображення нематеріальних активів (особливо критичної інфраструктури і загальнодержавного значення), що зумовлене втратою чинності низки підзаконних актів, зокрема:

- Постанови КМ України «Про затвердження Методики оцінки вартості майна під час приватизації» від 15.08.1996 р. № 961 (втратила чинність на підставі Постанови від 22.07.1998 р. № 1114);

- Постанови КМ України «Про затвердження Порядку визначення розміру частки, що належить державі у статутному капіталі господарських організацій, заснованих за участю держави на базі об'єднання майна різних форм власності» від 25.07.2012 р. № 686 (втратила чинність на підставі Постанови від 10.05.2018 р. № 388);

- Наказу ФДМ України «Про затвердження Порядку експертної оцінки нематеріальних активів» від 27.07.1995 р. № 969 (втратив чинність на підставі Наказу від 05.06.2013 р. № 775);
- Наказу ФДМ України «Про затвердження Порядку організації роботи державних органів приватизації під час визначення розміру частки, що належить державі у статутному капіталі господарських організацій, заснованих за участю держави на базі об’єднання майна різних форм власності» від 22.10.2012 р. № 3688 (втратив чинність на підставі Наказу від 10.04.2018 р. № 499).

Зазначені акти чітко визначали механізм дій i обов'язкову наявність документів для проведення оцінки вартості цілісного майнового комплексу й статутного відображення у капіталі підприємства звіту про оцінку нематеріальних активів (з розшифруванням за об'єктами, терміном введення та рівнем їх зносу), які нині не відображені в чинному законодавстві України, оскільки норми Закону України «Про оцінку майна, майнових прав та професійну оціночну діяльність в Україні» неповною мірою регламентують статус нематеріальних активів.

Результати приватизації 2014-2018 рр. засвідчили вкрай низьке використання Наказу Міністерства економіки України «Про затвердження Методичних рекомендацій щодо прогнозування наслідків та оцінки впливу на стан економічної безпеки держави приватизації деяких категорій підприємств» від 29.05.2009 р. № 518. Вказане призвело до розбалансування економічних напрямів розвитку України, відсутності прогнозування негативних наслідків і надання неякісної оцінки впливу на стан економічної безпеки держави у процесі приватизації підприємств, що мають ознаки домінування на ринку товарів, а також підприємств, що мають стратегічне значення для економіки і безпеки держави. У наслідку основні напрями державної політики 3 питань національної безпеки, що визначені нормами Закону України «Про національну безпеку України», залишаються нереалізованими, а низка профільних наказів і розпоряджень міністерств та відомств недієвими й суто декларативними (на кшталт Постанови КМ України «Про затвердження порядку встановлення чітких цілей діяльності для державних унітарних підприємств та господарських товариств, у статутному капіталі яких більше $50 \%$ акцій (часток) належить державі» від 09.11.2016 p. № 1052, або ж Наказу ФДМ України «Про порядок віднесення майна до такого, що включається до складу цілісного майнового комплексу державного підприємства» від 29.12.2010 р. № 1954).

Згідно з п. 5 ст. 116 Конституції України КМ України здійснює управління об'єктами державної власності відповідно до закону, а ВР України в межах повноважень, передбачених п. 3 ч. 1 ст. 85 і п. 7 ч. 1 ст. 92 Конституції України, приймає Закони України, зокрема які стосуються роздержавлення і в яких визначаються критерії заборони приватизації тих об’єктів, які мають 
загальнодержавне значення. Так, до об’єктів, що мають загальнодержавне значення, належать майнові комплекси підприємств, їх структурних підрозділів, основним видом діяльності яких $є$ виробництво товарів (робіт, послуг), що мають загальнодержавне значення.

При цьому, за ст. 6 Кодексу «Про надра», корисні копалини поділяються на об'єкти загальнодержавного і місцевого значення (ст. 39 Закону України «Про охорону навколишнього природного середовища»). Зарахування їх до таких груп здійснюється відповідно до Постанови КМ України «Про перелік корисних копалин загальнодержавного та місцевого значення» від 12.12.1994 p. № 827 (у редакції 16.08.2005 р. № 747).

Своєю чергою, абз. 2 ч. 2 ст. 4 Закону України «Про приватизацію державного і комунального майна» констатує, що приватизації не підлягають об’єкти права власності українського народу, у т.ч. які входять до активів державних підприємств, перебувають у них на балансі й використовуються ними (надра, корисні копалини загальнодержавного значення, водні ресурси, лісові ресурси, інші природні ресурси). Аналогічне значення мають i об'єкти стратегічного, загальнодержавного значення і критичної інфраструктури. Вказане вірно визначає, що саме не може бути приватизованим, однак цього недостатньо, оскільки загалом зміст законодавства має відповідати формі, а не залишатися декларованим на папері без дієвої реалізації, у зв'язку з чим Уряду й державному регулятору приватизації необхідно прийняти нормативні акти зобов'язального характеру щодо процедури обов'язкового відображення підприємствами нематеріальних активів з одночасним встановленням кримінальної відповідальності за ухилення і сприяння незаконним діям при роздержавленні.

Констатуємо, що за умови подальшої процедурної невизначеності суб'єкти підприємницької діяльності ставатимуть більш доступними саме тоді, коли в їх майновий комплекс, в порушення Наказу ФДМ України від 29.12.2010 р. № 1954, включаються необоротні активи (нематеріальні ресурси), які не підлягають роздержавленню на основі сфальсифікованих облікових фінансово-бухгалтерських даних. При цьому посадовці підприємства та органу приватизації ігнорують норми Постанови КМ України «Про затвердження методики оцінки майна» від 10.12.2003 р. № 1891, а також засади оцінки майна за Постановою КМ України «Національний стандарт № 1», бо не висвітлюють нематеріальні активи (у т.ч. право на користування природними ресурсами), чим завдають значних збитків державним інтересам.

У такому разі зацікавлені особи прагнуть в умовах законодавчого невизначення шляхом підлогу документів не відображати у складі майна підприємства необоротні (нематеріальні) активи, які безпосередньо утримуються з метою використання у виробництві, оскільки це розблоковує їх приватизацію. Вказане надає змогу привласнити й використовувати ліцензії (сертифікати, дозволи) на право експлуатації родовищ для видобування корисних копалин, що мають загальнодержавне значення й включені до державного фону родовищ корисних копалин. У цьому разі змінюються офіційні реєстраційні й установчі документи, що дає змогу ухилятися від включення в сукупну вартість майна комплексу низки активів згідно з положеннями постанов КМ України від 10.09.2003 р. № 1440 та від 10.12.2003 р. № 1891. Результат вказаного - проведена оцінка державної частки в майні підприємства не визначає справжнього розподілу капіталу й дійсної ринкової вартості всіх активів товариства, що не може братися за основу при відчуженні.

Таким чином, можливість приватизації державного підприємства випливає з кількох факторів, які взаємно пов'язані між собою і мають враховуватися посадовцями ФДМ України на етапі проведення аудиту й інвентаризації державного майна (зокрема спеціалізованих необоротних активів, що використовуються в єдиному технологічному процесі виробництва), для можливості визначення його критеріїв зарахування до активів загальнодержавного значення.

3 цією метою мають братися до уваги і відповідні форми державного статистичного спостереження за Наказом Держстату України «Про затвердження Методологічних положень з організації державного статистичного спостереження щодо капітальних інвестицій» від 31.10.2013 р. № 335 (у т.ч. № 13-зез «Звіт про прямі інвестиції»), які відображають державні необоротні активи під час створення спільних підприємств при істотному впливі іноземного капіталу (власність нерезидента складає від 10\% до $50 \%$ у вартості статутного капіталу). У такому разі застосовується експертна оцінка вартості таких активів, а іï порядок регламентується Міжнародними стандартами оцінки (методичний посібник № 4 «Нематеріальні активи») (МСО-2001), стандартами TEGOVA-2000 (методичний посібник № 8 «Нематеріальні активи»), а також Національними стандартами № 4 «Оцінка майнових прав інтелектуальної власності» та № 1 «Загальні засади оцінки майна і майнових прав».

В Україні здебільшого для використання результатів оцінки нематеріальних активів застосовується недосконалий П(С)БО № 8 «Нематеріальні активи», у зв'язку з чим при їх оцінці необхідно керуватися не тільки вимогами чинного законодавства, але й міжнародними стандартами, в яких реалізований передовий міжнародний досвід обліку таких специфічних об’єктів, як нематеріальні. 
Методологічні засади формування в бухгалтерському обліку інформації про нематеріальні активи визначені Наказом Мінфіну України «Про затвердження Положення (стандарту) бухгалтерського обліку» від 18.10 .1999 р. № 242, належний супровід відображення яких дасть змогу володіти фактичним станом справ щодо державних активів у процесі розкриття фінансової звітності.

Обов' язковість проведення інвентаризації майна, коштів і фінансових зобов'язань підприємств зумовлена (абз. 2 п. 12 Постанови КМ України «Про затвердження Порядку подання фінансової звітності» від 28.02.2000 р. № 419, абз. 2 п. 7 Наказу Мінфіну України «Про затвердження Положення про інвентаризацію активів та зобов'язань» від 02.09.2014 р. № 879) при певних випадках, зокрема при: приватизації майна державного підприємства; передачі майна державного підприємства (установи) в оренду; перетворення державного підприємства на акціонерне товариство. Таким чином, виведення і фіксація наявності необоротних активів обов'язкова матеріально відповідальними особами підприємства, яке проходить приватизаційну процедуру за етапами п. 21 розд. 2 Постанови КМ України «Про затвердження Положення про інвентаризацію майна державних підприємств, що приватизуються (корпоратизуються), а також майна державних підприємств та організацій, яке передається в оренду (повертається після закінчення строку дії договору оренди або його розірвання)» від 02.03.1993 р. № 158.

Об'єкти приватизації мають вірно відображатися в облікових формах задля раціонального та ефективного застосування способів відчуження через їх класифікацію, що особливо важливе при реалізації об’єктів групи «Г»:

- майнових комплексів або пакетів акцій, які на момент прийняття рішення про приватизацію займають монопольне (домінуюче) становище на загальнодержавному ринку товарів (робіт, послуг);

- особливо важливих народногосподарських комплексів, які забезпечують конкурентні переваги країни у виробництві складної техніки та економічну незалежність країни, а також володіють унікальними комплексами, що використовують рідкісні ресурси або їх комбінацію - нематеріальні активи з технологічними циклами.

Констатуємо, що питання вірного відображення майна у фінансово-господарській звітності державного підприємства на передприватизаційному етапі є важливим, оскільки, лише володіючи повною та достовірною інформацією про активи (у т.ч. нематеріальні), можна прийняти виважені рішення, які забезпечать державні інтереси й будуть суспільно корисними.
Держава, за наявності достовірної інформації про свої активи і відповідно до стратегічного бачення розвитку, зможе провести сортування підприємств за категоріями на ті зних, які треба залишити в державній власності, й ті, що будуть приватизовані, ліквідовані або передані в концесію, що зумовить чесну та прозору приватизацію для прогресивного економічного розвитку суспільства.

\section{1. Конституція УRL:} http://www.rada.gov.ua.

2. Податковий кодекс України. URL: http://www.rada.gov.ua.

3. Закон України «Про приватизацію державного і комунального майна». URL: http://liga.net.

4. Закон України «Про Фонд державного майна України». URL: http://liga.net.

5. Закон України «Про оцінку майна, майнових прав та професійної оціночної діяльності в Україні». URL: http://liga.net.

6. Постанова КМ України «Про затвердження порядку встановлення чітких цілей діяльності для державних унітарних підприємств та господарських товариств, у статутному капіталі яких більше 50 відсотків акцій (часток) належить державі» від 09.11.2016 р. № 1052. URL: http://www.rada.gov.ua.

7. Про затвердження методики оцінки майна : Постанова КМ України від 10.12.2003 р. № 1891. URL: http://www.rada.gov.ua.

8. Про затвердження Положення про інвентаризацію майна державних підприємств, що приватизуються (корпоратизуються), а також майна державних підприємств та організацій, яке передається в оренду (повертається після закінчення строку дії договору оренди або його розірвання) : Постанова КМ України від 02.03.1993 р. № 158. URL: http://www.rada.gov.ua.

9. Про затвердження Методичних рекомендацій щодо прогнозування наслідків та оцінки впливу на стан економічної безпеки держави приватизації деяких категорій підприємств : Наказ Мінекономіки України від 29.05.2009 p. № 518. URL: http://www.rada.gov.ua.

10. Про затвердження Положення (стандарту) бухгалтерського обліку : Наказ Мінфіну України від 18.10.1999 p. № 242. URL: http://www.rada.gov.ua.

11. Про порядок віднесення майна до такого, що включається до складу цілісного майнового комплексу державного підприємства : Наказ ФдМ України від 29.12.2010 p. № 1954. URL: http://liga.net.

12. Про затвердження Методологічних положень з організації державного статистичного спостереження щодо капітальних інвестицій : Наказ Держстату України від 31.10.2013 р. № 335. URL: http://liga.net.

13. Рябченко О.П. Державне управління відносинами власності в Україні. Вісник Харківського національного університету внутрішніх справ. 2000. № 10 . C. $192-196$.

14. Криштопа I.I. Оцінка нематеріальних активів: проблемні питання та напрямки їх вирішення. Галицький економічний вісник. 2010. № 1(26). С. 169-176.

15. Заруба П.І. Кримінальна відповідальність за злочини у сфері приватизації : Монографія. Київ : Атака, 2007. 220 с. 


\section{Анотація}

Палиулич $\boldsymbol{C}$. I. Проблемні питання приватизації нематеріальних активів та їх вплив на державні інтереси. - Стаття.

У статті на підставі перегляду матеріалів приватизаційної практики Фонду державного майна України та його регіональних відділень проаналізовані фактори і процеси, що впливають на незаконне роздержавлення. Розглянуте найбільш проблемне питання - невідображення серед державного майна нематеріальних активів, що включаються до приватизаційної маси основних засобів підприємства, а також охарактеризовані проблеми законодавчого регулювання вказаного процесу, що негативно впливає на реформування державної власності.

Розкриті аспекти необхідності дотримання критерію «економічної доцільності» при передачі об’єктів приватним власникам, а також збереження «державного інтересу» під час приватизації. При цьому проводився аналіз елементів і потреб держави в її існуванні й розвитку, особливо під час приватизації суб'єктів господарювання певних галузей та сфер, які обслуговують загальнодержавні інтереси та впливають на ії економічну безпеку. Автором наголошено, що кожен актив підприємства має бути належним чином облікованим, оціненим й зареєстрованим як основний засіб, що відображає загальну ринкову вартість об'єкту, який планується до приватизації. Підтверджене судження про відсутність належного фінансово-господарського обліку на важливих підприємствах, що часто призводить до розбалансування напрямів розвитку України й супроводжується нанесенням шкоди економічній безпеці держави. Таким чином, невідображення і недооцінка нематеріальних активів під час приватизації підприємств, що мають ознаки домінування на ринку товарів, мають стратегічне чи загальнодержавне значення, вкрай негативно впливають на стан економічної безпеки держави.
Ключові слова: державні інтереси, суспільні потреби, економічний потенціал, приватизація, необоротні активи, реформування власності.

\section{Summary}

Paltsulych Ye. I. Problem problems intangible assets and their effects on state interests. - Article.

The article analyzes the factors and processes affecting illegal denationalisation based on the review of materials of privatization practice of the State Property Fund of Ukraine and its regional offices. The most problematic issue of non-reflection of state-owned intangible assets included in the privatization mass of fixed assets of the enterprise is considered, as well as the problems of legislative regulation of the process are characterized, which negatively affects the reform of state property.

The aspects of necessity to observe the criterion of "economic expediency" in the transfer of objects to private owners, as well as preservation of "state interest" during privatization are revealed. At the same time, the elements and needs of the state in its existence and development were analyzed, especially during the privatization of economic entities of certain industries and spheres that serve the national interests and affect its economic security. The author emphasized that every asset of an enterprise should be properly accounted for, evaluated and registered as the maintool reflecting the total market value of the object planned for privatization. The statement about the lack of proper financial accounting at important enterprises is confirmed, which often leads to the imbalance of development directions of Ukraine and is accompanied by damage to the economic security of the state. Thus, it was estimated that non-displaying and underestimating intangible assets during the privatization of enterprises with signs of dominance in the market of goods, which have strategic or national importance, extremely negatively affect the state of economic security of the state.

Key words: state interests, public needs, economic potential, privatization, fixed assets, property reform. 